Gerontologia 1967;13:I-IV

\title{
Contents, Vol. 13, 1967
}

Gerontologia

Journal of Experimental Biological and Experimental Medical

Research on Ageing - Zeitschrift für experimentell-biologische und

-medizinische Alternsforschung - Journal de Recherches expéri-

mentales, biologiques et médicales, sur le vieillissement

Editor :

F. Verzár, Basel

\section{Coeditores}

F. Bourlière

D.A. Hal]

1 C.M.McCay

Paris

Leeds

Ithaca, N.Y.

Collaboratores :

A. v. Albertini, Zurich

H. Guth, Basel

W. Andrew,

H. P. von Hahn, Basel

Indianapolis, Ind.

L. Haranghy, Budapest

J. Baló, Budapest 
W. J. E. Jessop, Dublin

J. Banga, Budapest

V. R. Khanolkar, Bombay

L. Binet, Paris

P. S. Krishnan, Lucknow

J. E. Birren, Bethesda, Md

P.L. Krohn, Birmingham

G. H. Bourne, Atlanta, Ga.

P.J. Lindop, London

A. Comfort, London

K. Miescher, Basel

J. Danielli, London

H. Mislin, Mainz

W. DOBERAUER, Wie

O. Mühlbock, Amsterdam

G. Di Macco, Roma

R. Nicolaysen, Oslo

A. V. Everitt, Sydney

F. Roulet, Basel

K. J. Franklin, London

J. H. Sheldon, Wolverhampton

T. Geill, København

R. E. Tunbridge, Leeds

T. Gillman, Cambridge 

A. L. Vischer, Basel
E. Greppi, Firenze
R. Wagner, München
J. Groen, Jerusalem

A. Welford, Cambridge

1967

Vol. 13

BASEL (Switzerland) S. KARGER NEW YORK

Index

Bankowski, E.; Niewiarowski, S. and Galasinski, W.:

Platelet Aggregation by Human Collagen in Relation

to its Age 219

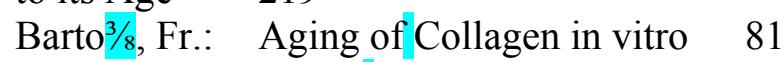

Batra, P. and Strehler, B. L.:

Beregi, Edit and Simon, J Birren, J. E.:

Studies on the Mechanism of Cell Death. IV. Alter

ations in Phosphorylative Capacity During Cell

Death 30

A Comparative Morphological Examination of the Earliest Allergic Lesions in Old and Young Animals 144

vide Riegel, K. F.

Boros-Farkas, Maria and Everitt, A. V.:

37

Comparative Studies of Age Tests on Collagen Fibres

Boros-Farkas, Maria and Verzár, F.:

50

Influence of Different Sugars on the Survival of

Hypophysectomised Rats

Boros-Farkas, Maria ; Hahn, H. P. von and Verzár, F.:

Calcification of Rat Skin by Induced Dehydrota-

chysterol. П. Changes in Calcium, Phosphorus and

Protein 136

Boros-Farkas, Maria; Spichtin, H. and Verzár, F.:

129

Calcification of Rat Skin Induced by Dehydrota-

chysterol. I. Changes in Collagen

Bourlière, F.: Carpenter, D. G

vide Parot, $\mathrm{S}$.

Carpenter, J. A. and Loynd, J. A.:

Ill 
Computer Solutions for Diffusion Theory Equations on the Accumulation of Cross-Linked

Molecules . .

Carpenter, J. A.: $\quad$ vide Carpenter, D. G.

Chvapil, M.: vide Hriïza, Z.

Dalderup, Louise M.; Keller, G. H. M. and Stroo, Maria M.:

Fat, Ash and Calcium Contents of Rat Heart Tissue,

Elasticity of the Aorta and Microscopical Vascular

Changes in Rats of Different Ages

Das, B. C.: $\quad$ Linear and Curvilinear Functional Relationships

Between Human Blood Components and Age ...

Dlouhá, M.: vide Hrûza, Z.

Dupuch, G. H.: $\quad$ vide Ring, G. C.

86

227

Index

Everitt, A. V.: vide Boros-Farkas, Maria

Everitt, A. V.: vide Giles, J. S.

Galasinski, W.: $\quad$ vide Bankowski, S.

Giles, J. S. and Everitt, A. V.:

The Role of the Thyroid and Food Intake in the Ageing of Collagen Fibres. I. In the Young Rat . .65

Greed, J.: $\quad$ vide Ring, G. C.

Hahn, H. P. von: $\quad$ vide Boros-Farkas, Maria

Hlavackova, V.: $\quad$ vide Hrûza, Z.

Hrûza, Z. and Hlavackova, V.:

Effect of Decalcification on Chemical Contraction

and Relaxation of Collagen Fibres 246

Hrûza, Z.; Chvapil, M. and Dlouhá, M.:

The Influence of Age, Sex and Genetic Factors on

the Mechanical and Physico-Chemical Structural

Stability of Collagen Fibres in Mice 20

Jones, D. G.; Osborn, G. K. and Kimeldorf, D. J.:

Cardiac Arrhythmia in the Aging Male Rat . . . 211

Keller, G. H. M.: $\quad$ vide Dalderup, Louise M.

Kimeldorf, D. J.: $\quad$ vide Jones, D. C.

Küstner, R.: vide Wünscher, W.

Loevén, W. A.: $\quad$ Elastoproteinase and Elastomucases: The Effect of

Age on the Enzyme Content in Human Pancreas . 200

Loynd, J. A.: vide Carpenter, D. G.

Mainwaring, W. I. P.: The Ageing Process in the Mouse Ventral Prostate

Gland: A Preliminary Biochemical Survey . . . 177

Mende, T. J. and Viamonte, L.:

Studies on Chloral Hydrate and Camphor Sensitivity

in Rats of Different Ages 165 
Németh-Csóka, M.: Changes in Uptake of S35-Sulfate by Carrageenin Granuloma in Normal and Lathyritic Rats of Differ

ent Ages $\quad 70$

Niewiarowski, S.: $\quad$ vide Bankowski, E.

Osborn, G. K.: vide Jones, D. C.

Parot, S. et Bourlière, F.: Une nouvelle technique de mesure de la compreßsi-bilité de la peau et du tissu sous-cutané. Influence du sexe, de l'âge et du site de mesure sur les résultats 95

Patnaik, B. K.:Effect of Age on the Oxygen Consumption and Glu-

cose Uptake by the Elastic Cartilage of Rat . . . 173

Rapaport, A.: L'adaptation du comportement du rat jeune, adulte

et age aux variations de la temperature ambiante.

I. Adaptation au froid 14

Riegel, K. F. and Birren, J. E.:

Age Differences in Choice Reaction Times to Verbal

Stimuli 1

Index

Ring, G. C.; Dupuch, G. H. and Creed, J.:

The Effect of Voluntary Exercise on the Resting

Oxygen Consumption of Rats 194

Simon, J.: vide Beregi, Edit

Spightin, H.: vide Boros-Farkas, Maria

Strehler, B. L.:vide Batra, P.

Strod, Maria M.: $\quad$ vide Dalderup, Louise M.

Verzár, F.: $\quad$ vide Boros-Farkas, Maria

Viamonte, L.: vide Mende, T. J.

Wünscher, W. und Küstner, R.:

Untersuchungen über die mengenmässigc Verteilung von Lipofuszin und Vitamin-E-Mangel-Pig-

ment in Nervenzellen von Ratten verschiedener

Altersstufen 153

In Memoriam Clive M. McCay 193

Book Reviews - Buchbesprechungen - Livres Nouveaux 63, 124, 190

Varia 64

Index Rerum ad Vol. $13 \quad 253$

All rights, including that of translation into other languages, reserved.

Photomechaníc reproduction (photocopy, microcopy) of this volume or parts thereof without special

permission of the publishers is prohibited.

(C)

Copyright 1967 by S.Karger AG, Basel

Printed in Switzerland by Buchdruckerei National-Zeitung AG, Basel

Cliches: Aberegg-Steiner \& Cie. AG, Bern 